\title{
Male territorial behaviour of the endemic large carpenter bee, Xylocopa (Koptortosoma) ogasawarensis (Hymenoptera: Apidae), on the oceanic Ogasawara Islands
}

\author{
SHINII SUGIURA \\ Department of Forest Entomology, Forestry and Forest Products Research Institute (FFPRI), 1 Matsunosato, Tsukuba, Ibaraki \\ 305-8687, Japan; e-mail: ssugiura@ffpri.affrc.go.jp
}

Key words. Hymenoptera, Apidae, flower-visiting behaviour, interference, Xylocopa (Koptortosoma) ogasawarensis, flower-based territoriality

\begin{abstract}
The endemic large carpenter bee, Xylocopa (Koptortosoma) ogasawarensis Matsumura (Hymenoptera: Apidae), on the oceanic Ogasawara (Bonin) Islands, located in the northwestern Pacific Ocean, approximately $1000 \mathrm{~km}$ south of the Japanese mainland, is a generalist flower visitor. Although the flower-visiting behaviour of $X$. ogasawarensis females has been frequently recorded, the behaviour of the males in this species has rarely been studied. I observed the territorial behaviour of males on flowers of the native plant species Scaevola sericea Vahl (Campanulales: Goodeniaceae) in a coastal area of Hahajima in early July 2007. Each male chose a particular inflorescence, hovered near it (mean distance, $239 \mathrm{~mm}$ from the inflorescence) and patrolled around it for several minutes (mean time, $331 \mathrm{~s}$ ). Therefore, X. ogasawarensis males exhibit resource-based (i.e., flowers) territoriality. Males frequently attacked other males when defending their territories. However, males did not defend their territories against flower visitors of other species (i.e., introduced honeybees). Therefore, male territorial behaviour in X. ogasawarensis may be related to intrasexual competition for sites visited by females. This is the first report describing the male territorial behaviour of $X$. ogasawarensis.
\end{abstract}

\section{INTRODUCTION}

Mating and territorial behaviour of males is reported for many bee species (Alcock et al., 1978; Eickwort \& Ginsberg, 1980; Ayasse et al., 2001; Paxton, 2005). The sites where this behaviour occurs differ among bee species, e.g., nesting sites, emergence sites, overwintering sites, or food-plant flowers (Alcock et al., 1978; Ayasse et al., 2001; Sugiura et al., 2007). Large carpenter bees of the genus Xylocopa Latreille (Hymenoptera: Apidae) are interesting because the mating and territorial behaviour of male bees is very variable in this group (Gerling et al., 1989; Leys, 2000; Leys et al., 2000). The genus Xylocopa contains 469 species of moderately large to very large bees that are distributed over all continents, predominantly in tropical and subtropical climates (Michener, 2000). The genus Xylocopa consists of 31-51 subgenera, depending on the classification (Leys et al., 2002). Xylocopa males basically have three different ways of searching for females (Gerling et al., 1989; Leys, 2000): (1) searching at nesting sites, flowers, or landmarks (nonterritoriality); (2) monopolizing resources important to females, like flowers or nesting sites (resource-based territoriality); and (3) monopolizing areas lacking resources for females (nonresourcebased territories, or leks). Although different types of matesearching behaviour are reported for males, even within the same species of Xylocopa, some phylogenetic patterns in the mate-searching behaviour of Xylocopa males have been suggested (Leys, 2000). For example, nonresource territoriality seems to be characteristic for species in the subgenera Neoxylocopa Hurd \& Moure and Koptortosoma Gribodo. However, further data on mating and territorial behaviour of Xylocopa (sensu lato) are needed in order to generalize these phylogenetic patterns.

The genus Xylocopa includes a few important endemic species on isolated oceanic islands that have never been connected to a continental landmass. Unique biotas are found on such islands because of the separate evolution and speciation of immigrant organisms (Carlquist, 1974; Gillespie \& Roderick, 2002). Because isolated oceanic islands originally lacked social bees, endemic solitary bees are considered to be important pollinators of oceanic island plants (Kato, 1992; Kato \& Nagamasu, 1995; Olesen et al., 2002; Daly \& Magnacca, 2003; Dupont et al., 2003; Abe, 2006; Philipp et al., 2006). Xylocopa (Neoxylocopa) darwini Cockerell, which is the only native (and endemic) bee species on the oceanic Galápagos islands, is known to visit the flowers of 79 plant species and is considered an important pollinator on these islands (Linsley et al., 1966; McMullen, 1993; Philipp et al., 2006). Xylocopa (Koptortosoma) ogasawarensis Matsumura, one of nine endemic solitary bees on the oceanic Ogasawara (Bonin) Islands (Kato, 1992; Kato et al., 1999), is also a generalist flower visitor and is considered an important pollinator of the plants on these islands (Goubara, 2002; Abe, 2006). On isolated oceanic islands, ecological release due to enemy- or competitor-free conditions is known to have induced endemic organisms to change their behaviour and habitats (e.g., Carlquist, 1974). Therefore, to generalize, the phylogenetic patterns in male territorial behaviour within the genus Xylocopa (sensu lato) make it particularly interesting for an investigation of the male behaviour of endemic island species. Males of $X$. darwini are recorded as defending shrubs or dead wood, but not flowers or nesting sites, i.e., they show nonresource territoriality (Linsley, 1965). However, male territorial behaviour in $X$. ogasawarensis is not described in detail. Here the territorial behaviour of male $X$. ogasawarensis in which male bees defend territories around the flowers of a native plant species against other males is reported. This is the first report describing the male territorial behaviour of $X$. ogasawarensis. 

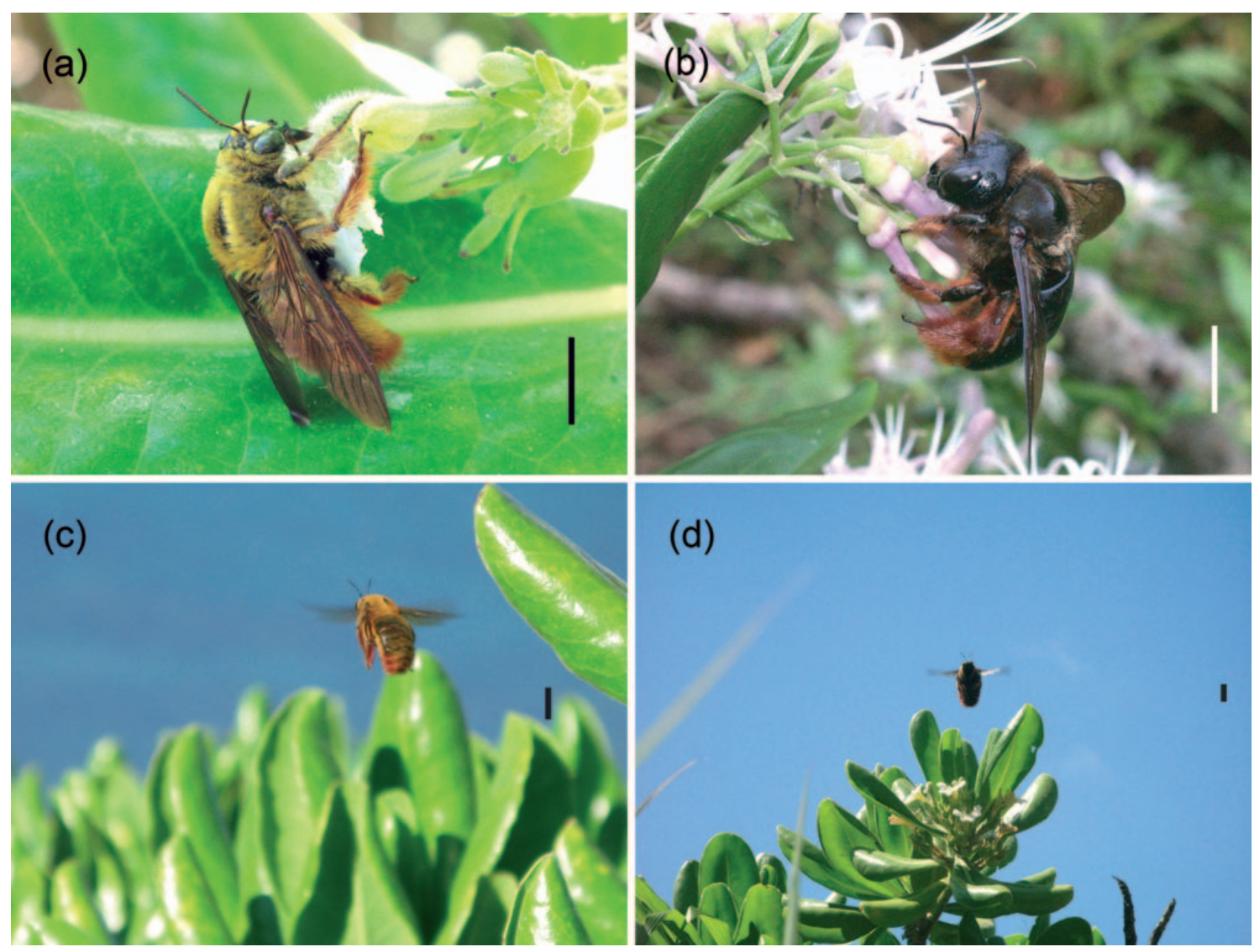

Fig. 1. Flower-visiting and territorial behaviour of Xylocopa ogasawarensis. (a) Male visiting a Scaevola sericea flower. (b) Female visiting flowers of the endemic Hedyotis leptopetala. (c) Male patrolling S. sericea shrubs. (d) Male hovering and defending his territory around $S$. sericea inflorescences. Scale bars: $10 \mathrm{~mm}$.

\section{MATERIAL AND METHODS}

\section{Study site and species}

The Ogasawara Islands are located in the northwestern Pacific Ocean approximately $1000 \mathrm{~km}$ south of the Japanese mainland (Shimizu, 2003). The endemic large carpenter bee X. ogasawarensis is the only species of the genus and the largest bee found on the islands (Sakagami, 1961; Ohbayashi et al., 2003). Male and female $X$. ogasawarensis are easily distinguished in the field by their conspicuous sexual dimorphism (as in other species of the subgenus Koptortosoma), the coloration of males is yellowish (Fig. 1a) and that of females brownish (Fig. 1b; Sakagami, 1961). As in other species of Xylocopa, each female of $X$. ogasawarensis makes a single nest by digging a hole in the dead branches of trees. Nest-site searching and nesting behaviour of females are frequently observed on the islands in May-July (Goubara, 2002; Sugiura, unpubl. data).

\section{Methods}

The territorial behaviour of $X$. ogasawarensis males on flowers of a native plant species, Scaevola sericea Vahl (Campanulales: Goodeniaceae), was observed at Samegasaki, a coastal area on Hahajima (Fig. $1 \mathrm{c} ; 26^{\circ} 38^{\prime} \mathrm{N}, 142^{\circ} 09^{\prime} \mathrm{E}$; elevation 2-9 m). The vegetation at this coastal site was mainly composed of $S$. sericea shrubs. The height of the $S$. sericea ramets ranged from 0.25 to $2.1 \mathrm{~m}$ and the flowers developed from the axillary buds of shoots. To determine the significance of male territorial behaviour, $S$. sericea shrubs growing along a trail 30 $\mathrm{m}$ in length were observed for about $8 \mathrm{~h}$ on five sunny days: $15: 15-16: 30$ on 1 July; $9: 30-10: 30$ and $16: 00-17: 00$ on 2 July; $8: 50-10: 00$ and $16: 20-16: 50$ on 3 July; $8: 45-9: 45$ and $15: 40-16: 40$ on 4 July; and $8: 25-9: 35$ on 5 July 2007 . No $X$. ogasawarensis individuals were observed from 10:30 to $15: 00$ on flowers of $S$. sericea on any day. Three categories of male behaviour were recorded: nectar-feeding (Fig. 1a), territoriality (Fig. 1c, d) and resting.

The time spent defending territories (i.e., hovering and patrolling near flowers) by territorial males at the site was recorded to the nearest second with a stopwatch $(n=17)$. When males left their territories, the height and distance from inflorescences of male hovering sites was measured to the nearest $10 \mathrm{~mm}$ using a tape measure $(n=30)$. To determine whether male bees choose inflorescences with the greater number of flowers, the number of flowers between defended $(n=18)$ and randomly selected inflorescences $(n=18)$ were compared on 4 July. A generalized linear model (GLM) with Poisson error distribution was used to test the difference (JMP ver. 6.0; SAS Institute, 2005). When males attacked other males in the defence of their territories, I recorded whether or not the territorial males were successful ( $n$ $=25$ ). This behaviour was observed from a short distance from their territories (ca. 3-5 m).

To clarify the relationship between flowers visited by females and the territorial behaviour by males, I collected flower- 
TABLE 1. Records of flower-visiting behaviour by Xylocopa ogasawarensis by plant species.

\begin{tabular}{|c|c|c|c|c|c|c|}
\hline Family & Species & Status $^{2}$ & $\begin{array}{l}\text { Life } \\
\text { form }\end{array}$ & $\begin{array}{l}\text { Time of } \\
\text { flowering }\end{array}$ & $\begin{array}{l}\text { Sexes of } X \\
\text { ogasawarensis }\end{array}$ & References \\
\hline Asteraceae & Helianthus annuиs & Cultivated & Herb & May & Female & Ogasawara, pers. obs. \\
\hline Campanulaceae & Lobelia boninensis & Endemic & Herb & May-Nov. & Female & $\begin{array}{l}\text { Kato et al., 1999; Goubara, 2002; } \\
\text { Abe, } 2006\end{array}$ \\
\hline Clusiaceae & Calophyllum inophyllum & Indigenous & Tree & Jun.-Sep. & Female/Male ${ }^{3}$ & Abe, 2006; Wada, pers. obs. \\
\hline Compositae & Dendrocacalia crepidifolia & Endemic & Tree & Nov.-Dec. & Female & Goubara, 2002 \\
\hline Convolvulaceae & $\begin{array}{l}\text { Ipomoea pes-caprae subsp. } \\
\text { brasiliensis }\end{array}$ & Indigenous & Herb & Jun.-Dec. & Female/Male & Abe, 2006; Sugiura, unpubl. data \\
\hline Elaeocarpaceae & $\begin{array}{l}\text { Elaeocarpus photiniaefo- } \\
\text { lius }\end{array}$ & Endemic & Herb & Jun.-Aug. & Female & Goubara, 2002 \\
\hline Fabaceae & Leucaena leucocephala & Alien & Tree & Jun.-Dec. & Female & Wada, pers. obs.; Kawazoe, pers. obs. \\
\hline Fabaceae & Canavalia lineata & Indigenous & Herb & May-Aug. & Female & Goubara, 2002; Kawazoe, pers. obs. \\
\hline Goodeniaceae & Scaevola sericea & Indigenous & Shrub & May-Oct. & Female/Male ${ }^{3}$ & Kato, 1992; Abe, 2006; this study \\
\hline Malvaceae & Hibiscus glaber ${ }^{1}$ & Endemic & Tree & Jun.-Dec. & Female & $\begin{array}{l}\text { Kato, 1992; Abe, 2006; Sugiura, } \\
\text { unpubl. data }\end{array}$ \\
\hline Malvaceae & Hibiscus tiliaceus $^{1}$ & Indigenous & Tree & Jun.-Dec. & Female & Tanaka, 1991 \\
\hline Melastomataceae & Melastoma tetramerum & Endemic & Shrub & Jul.-Sep. & Female & Goubara, 2002; Abe, 2006 \\
\hline Melastomataceae & $\begin{array}{l}\text { Melastoma tetramerum } \\
\text { var. pentapetalum }\end{array}$ & Endemic & Shrub & Jul.-Aug. & Female & Abe, 2006 \\
\hline Myrtaceae & Metrosideros boninensis & Endemic & Tree & Aug.-Oct. & Female & Abe, 2006; Sugiura, unpubl. data \\
\hline Myrtaceae & Syzygium cleyerifolium & Endemic & Tree & Jul. & Female & Wada, pers. obs. \\
\hline Palmae & Clinostigma savoryanum & Endemic & Tree & Jun.-Aug. & Female & Sugiura, unpubl. data \\
\hline Ranunculaceae & Clematis boninensis & Endemic & Vine & Jul.-Nov. & Female & Abe, 2006 \\
\hline Rosaceae & Rubus nakaii & Endemic & Shrub & Apr.-May & Female & Nagata, 2003 \\
\hline Rubiaceae & Hedyotis leptopetala & Endemic & Shrub & Jul.-Dec. & Female & Abe, 2006, Sugiura, unpubl. data \\
\hline Theaceae & Schima mertensiana & Endemic & Tree & Mar.-Jun. & Female/Male ${ }^{3}$ & $\begin{array}{l}\text { Kato, 1992; Abe, 2006; Sugiura, } \\
\text { unpubl. data; Wada, pers. obs. }\end{array}$ \\
\hline Verbenaceae & Callicarpa subpubescens & Endemic & Tree & Apr.-Aug. & Female & Kawakubo, 1998 \\
\hline Verbenaceae & Stachytarpheta jamaicensis & Alien & Herb & Feb.-Dec. & Female & Wada, pers. obs. \\
\hline Zingiberaceae & Alpinia boninsimensis & Endemic & Herb & Jun.--Jul. & Female & Abe, 2006 \\
\hline
\end{tabular}

${ }^{1}$ Nectar of the plant is robbed by $X$. ogasawarensis; ${ }^{2}$ Indigenous: nonendemic native; ${ }^{3}$ Males observed hovering near flowers.

visiting records of $X$. ogasawarensis from previous studies. When the sex of the individuals visiting flowers was not recorded, I asked the investigators for this information. Furthermore, I collected the flower-visiting records of $X$. ogasawarensis from several investigators and local naturalists. The species and sex can easily be identified by anyone in the field because of the large size of the species and this sexual colour dimorphism (Fig. 1a, b). Status (cultivated, alien, endemic, or nonendemic native), life forms (herb, vine, shrub, or tree), and flowering periods (months) of each plant species visited by $X$. ogasawarensis were obtained from Toyoda (2003) and Abe et al. (2004).

\section{RESULTS}

I observed 80 independent periods of territorial behaviour by $X$. ogasawarensis males. Although several of these observations may be for the same males, 3-5 males were observed hovering at the same time on each study day. Males hovered $239 \pm 75$ $\mathrm{mm}$ (mean $\pm \mathrm{SD}$ ) away from inflorescences (Fig. 1c, d) $887 \pm$ $325 \mathrm{~mm}$ above the ground and circled (patrolled) around the inflorescences.

The maximum diameter of the territories ranged from about 0.5 to $2.0 \mathrm{~m}$, although it could not be accurately measured. Time spent defending territories ranged from 29 to $873 \mathrm{~s}$ (mean \pm SD, $331 \pm 256 \mathrm{~s}$ ). Some hovering males were frequently observed touching the defended inflorescences momentarily, suggesting that they marked their own territories with a secretion. The number of open flowers did not differ between male-defended and randomly selected inflorescences [GLM, $d f=1, \chi^{2}=0.026$, $P=0.87$; median (range), defended, 3 (2-7) vs. randomly selected, 3 (1-9)]. Thus, territorial male bees did not choose inflorescences of $S$. sericea with the greatest number of flowers.

Territorial males were frequently observed to attack other males that invaded their territories and/or fed on the nectar of defended flowers. Each territory-defending male made a direct frontal attack on an invading male and chased it out of its territory (c.f., Linsley, 1965; Barrows, 1983). At least $80 \%$ of the territorial interactions between males resulted in the successful defence by the territorial holder and at least $4 \%$ resulted in the loss of the territory; other outcomes could not be successfully determined. Nectar-feeding honeybees (the introduced Apis mellifera $\mathrm{L}$.) were observed visiting flowers defended by $X$. ogasawarensis males on two occasions; neither territorial male defended its territory against these flower-visitors and did not chase the honeybees away.

Thirteen and 3 independent periods of nectar-feeding by males and females, respectively, were observed at the study site. Both males and females took nectar from undefended $S$. sericea flowers. Three males were observed resting on leaves of $S$. sericea, suggesting that males may not be active from 10:30 to 
15:00 during the day, although females were seen flying to their nests or searching for nest sites in the forest.

The flower-visiting behaviour of $X$. ogasawarensis is recorded for at least 23 plant taxa (Table 1). Most flowervisiting behaviour is documented for females, with only four plant species reported for males (Table 1). Male hovering behaviour was observed around flowers of three plant species: Schima mertensiana (Siebold \& Zuccarini) Koidz. (Theaceae), Calophyllum inophyllum Linnaeus (Clusiaceae) and S. sericea. The flowering periods of these species coincide with the provisioning period of $X$. ogasawarensis (May-July).

\section{DISCUSSION}

Territorial behaviour of the males of the genus Xylocopa is generally related to mate searching and mating behaviour (e.g., Gerling et al., 1989). Flowers are important encounter sites for male and female bees (Eickwort \& Ginsberg, 1980). Flowerbased territorial behaviour of male bees is recorded in Xylocopa species (Gerling et al., 1989), as well as in several solitary bee species (Alcock et al., 1978; Severinghaus et al., 1981; Sugiura et al., 2007). Xylocopa ogasawarensis males hovered near inflorescences of the native plant species $S$. sericea, patrolled around them and defended the area against other males (Fig. 1d). Therefore, $X$. ogasawarensis males hold a resource-based (flowers) territory. Because different types of male territorial behaviour are reported even within the same species of bees including Xylocopa (Leys, 2000; Paxton 2005), X. ogasawarensis males may also display other types of territorial behaviour such as nonresource territoriality or other resource-based, e.g., nest site territoriality.

Females of $X$. ogasawarensis are polylectic (generalists) as they visit the flowers of many plant species (Table 1). Males of polylectic bees may mate at other sites than flowers (e.g., nest sites), because they are less likely to encounter mates on a given food plant than males of oligolectic (specialist) bees. However, females of $X$. ogasawarensis mainly visit flowers of a few plant species during the provisioning period, e.g., Schima mertensiana and Scaevola sericea in June (Sugiura, unpubl. data). The nest sites that females frequently search for or return to are sparsely distributed in forests. Thus, $X$. ogasawarensis males can more easily find flowers than nest sites during the provisioning period (May-July; Table 1). Mating in many species of bee occurs in the male's territory, although different mating sites are reported even within the same species (reviewed by Paxton, 2005). Therefore, flower-based territorial behaviour in X. ogasawarensis males appears to be closely associated with searching for mates and/or mating, although mating in $X$. ogasawarensis has not been observed.

Males of $X$. ogasawarensis frequently attacked and drove other males from their territories. However, males did not defend their territories against flower-visitors of other species (i.e., honeybees). Xylocopa ogasawarensis males did not chase other insects, unlike males of other Xylocopa species (Linsley, 1965; Barrows, 1983). Therefore, the male territorial behaviour of $X$. ogasawarensis may be related to intrasexual competition for sites visited by females.

ACKNOWLEDGEMENTS. I thank T. Abe, K. Wada, K. Ogasawara, T. Yasui, K. Kawazoe and Y. Hoshi for providing valuable flower-visiting records for $X$. ogasawarensis. I also thank S. Makino, T. Abe and Y. Yamaura for advice and help with this study and the staff of the National Forest Division of the Ogasawara General Office for permission to use the study site. This study was supported by funding from the Global Environmental Research Fund (F-051).

\section{REFERENCES}

ABE T. 2006: Threatened pollination system in native flora of the Ogasawara (Bonin) Islands. Ann. Bot. 98: 317-334.

Abe T., Yasui T., Wada K., Wada M., Kato Y., Makino S. \& Окосні I. 2004: Observation records of flowering period of plants in the Ogasawara Islands. Bull. For. For. Prod. Res. Inst. 3: 249-257.

Alcock J., Barrows E.M., Gordh G., Hubbard L.J., Kirkendall L., Pyle D.W., Ponder T.L. \& Zalom F.G. 1978: The ecology and evolution of male reproductive behaviour in the bees and wasps. Zool. J. Linn. Soc. 64: 293-326.

Ayasse M., PAXton R.J. \& Tengö J. 2001: Mating behavior and chemical communication in the order Hymenoptera. Annu. Rev. Entomol. 46: 31-78.

BARrows E.M. 1983: Male territoriality in the carpenter bee Xylocopa virginica virginica. Anim. Behav. 31: 806-813.

CARlquist S. 1974: Island Biology. Columbia University Press, New York, 660 pp.

Daly H.V. \& Magnacca K.N. 2003: Hawaiian Hylaeus (Nesoprosopis) bees (Hymenoptera: Apoidea): Insects of Hawaii vol. 17. University of Hawaii Press, Honolulu, 234 pp.

Dupont Y.L., Hansen D.M. \& Olesen J.M. 2003: Structure of a plant-flower-visitor network in the high-altitude sub-alpine desert of Tenerife, Canary Islands. Ecography 26: 301-310.

EIckwort G.C. \& Ginsberg H.S. 1980: Foraging and mating behavior in Apoidea. Annu. Rev. Entomol. 25: 421-446.

Gerling D., Velthuis H.H.W. \& Hefetz A. 1989: Bionomics of the large carpenter bees of the genus Xylocopa. Annu. Rev. Entomol. 34: 163-190.

Gillspie R.G. \& Roderick G.K. 2002: Arthropods on islands: colonization, speciation, and conservation. Annu. Rev. Entomol. 47: 595-632.

Goubara M. 2002: Bee fauna and its conservation on the Ogasawara Islands. In Sugiura N., Ito F. \& Maeta Y. (eds): Natural History of Bees, Wasps and Ants. Hokkaido University Press, Sapporo, pp. 229-245 [in Japanese].

KATO M. 1992: Endangered bee fauna and its floral hosts in the Ogasawara Islands. Jap. J. Entomol. 60: 487-494.

Kato M. \& Nagamasu H. 1995: Dioecy in the endemic genus Dendrocacalia (Compositae) on the Bonin (Ogasawara) Islands. J. Plant Res. 108: 443-450.

Kato M., Shibata A., Yasui T. \& Nagamasu H. 1999: Impacts of introduced honeybees, Apis mellifera, upon native bee communities in the Bonin (Ogasawara) Islands. Res. Popul. Ecol. 41: 217-228.

KaWAKUBo N. 1998: Evolution of cryptic dioecy in Callicarpa (Verbenaceae) on the Bonin Islands. In Stuessy T.F. \& Ono M. (eds): Evolution and Speciation of Island Plants. Cambridge University Press, Cambridge, pp. 155-168.

LEYS R. 2000: Mate locating strategies of the green carpenter bees Xylocopa (Lestis) aeratus and X. (L.) bombylans. $J$. Zool. 252: 453-462.

Leys R., Cooper S.J.B. \& Schwarz MP. 2000: Molecular phylogeny of the large carpenter bees, genus Xylocopa (Hymenoptera: Apidae), based on mitochondrial DNA sequences. Mol. Phyl. Evol. 17: 407-418.

Leys R., Cooper S.J.B. \& Schwarz MP. 2002: Molecular phylogeny and historical biogeography of the large carpenter bees, genus Xylocopa (Hymenoptera: Apidae). Biol. J. Linn. Soc. 77: 249-266.

LinSLEY E.G. 1965: Notes on male territorial behavior in the Galapagos carpenter bee (Hymenoptera: Apoidea). Pan-Pac. Entomol. 41: 158-161. 
Linsley E.G., Rick C.M. \& Stephens S.G. 1966: Observations on the floral relationships of the Galápagos carpenter bee. Pan-Pac. Entomol. 42: 1-18.

McMullen C.K. 1993: Flower-visiting insects of the Galapagos Islands. Pan-Pac. Entomol. 69: 95-106.

Michener C.D. 2000: The Bees of the World. The Johns Hopkins University Press, Baltimore and London, $913 \mathrm{pp}$.

Nagata Y. 2003: Rubus nakaii. In Yahara T. \& Nagata Y. (eds): Red Data Plants. Yamakei, Tokyo, 277 pp. [in Japanese].

Ohbayashi T., Inaba M., Suzuki H. \& Kato M. 2003: List of insects in Ogasawara Islands, Japan (2002 ver.). Ogasawara Res. 29: 17-74 [in Japanese with English abstr.].

Olesen J.M., Eskildsen L.I. \& VenKatasamy S. 2002: Invasion of pollination networks on oceanic islands: importance of invader complexes and endemic super generalists. Divers. Distr. 8: 181-192.

PAXTON R.J. 2005: Male mating behaviour and mating systems of bees: an overview. Apidologie 36: 145-156.

Philipp M., Böcher J., Siegismund H.R. \& Nielsen L.R. 2006 Structure of a plant-pollinator network on a pahoehoe lava desert of the Galápagos Islands. Ecography 29: 531-540.
SAKagami S.F. 1961: On the male of Xylocopa ogasawarensis Matsumura (Hymenoptera, Apidae). Insecta Matsumur. 24: 115-120.

SAS Institute 2005: JMP Ver. 6.0: Statistics and Graphics Guide: Japanese Edition. SAS Campus Drive, Cary, USA, 927 pp. [in Japanese].

Severinghaus L.L., Kurtak B.H. \& Eickwort G.C. 1981: The reproductive behavior of Anthidium manicatum (Hymenoptera: Megachilidae) and the significance of size for territorial males. Behav. Ecol. Sociobiol. 9: 51-58.

Shimizu Y. 2003: The nature of Ogasawara and its conservation. Global Environ. Res. 7: 3-14.

Sugiura S., Abe T., Yamaura Y. \& Makino S. 2007: Flowervisiting behavior of male bees is triggered by nectar-feeding insects. Naturwissenschaften 94: 703-707.

TANAKA H. 1991: Pollination ecology of flowering plants on Chichijima. Ogasawara-Kenkyu-Nenpo 18: 44-53 [in Japanese].

TOYODA T. 2003: Floral of Bonin Islands (Enlarged and Revised). Apoc, Kamakura, 522 pp. [in Japanese].

Received August 23, 2007; revised and accepted October 8, 2007 